\title{
THE EFFECT OF FINANCIAL EXPERTISE ON COMPENSATION AND BOARD OF DIRECTORS TURNOVER
}

\author{
Danar Irianto ${ }^{1)}$, Nuranisa Anugerah ${ }^{2)}$ \\ Managerial Accounting study Program, Batam Polytechnics \\ Parkway Street, Batam Centre, Batam 29461, Indonesia \\ ${ }^{1)}$ Email: danaririanto@gmail.com \\ ${ }^{2)}$ Email: anugerah.anisa@gmail.com
}

\begin{abstract}
This research aims to explains association between financial expertise of directors to directors compensation and directors turnover of Indonesia non financial company in 2011-2012. Using ordinary least square regression we used four variables to define financial expertise of directors: age of the directors, tenure of the directors, the postgraduate degree (MBA), and the accounting certification (CPA). However, this study found no association financial expertise to compensation and directors turnover. We hope this study can contributes to financial expertise, compensation, and turnover literature. We also provide implications for companies in determining the compensation of directors based on financial expertise. Further research can be improve by add new variabel such as complexcity and board size.
\end{abstract}

Keywords: Compensation, Directors' Turnover, Fiancial Expertise, IFRS 


\section{Introduction}

\subsection{Background}

Begins with sarbanes oxley act 2002 that signed in chicago, an important role director and chief financial officer became the most topic discussed. One of the mai contents of Sarbanes Oxley Act is to require $\mathrm{CEO}$ and $\mathrm{CFO}$ to certify the validity of financial reporting(Suradi, 2012).

The purpose of creating financial statements is to generate information became useful information for making decisions. In preparing the financial statements, Indonesia adopted the new standard of GAAP to IFRS. Indonesia is gradually adopting IFRS. Starting from 2008 until 2011 as transition period of period, and full adopted IFRS in 2012.

This research will use 2011 and 2012 as research year. In that year all members of the board of directors are in the same position, where the directors must be able to understand, apply and provide training to members in implementing the new standards. In this position, the board of directors can provide expertise in applying new standards, so financial expertise of directors becomes the key of preparing accurate financial statements for the year.

The existence of Sarbanes oxley act has enhanced research related to the role of the directors on the quality of financial statements. Loyeung (2014) examines the relationship between the financial director's accounting talents, compensation and change of finance director. Woning (2014) examines the relationship between the complexity of the work of the finance director to the compensation and performance of the finance director. Burks (2007) examines the relationship between the Sarbanes Oxley Act's impact on re-reporting and compensation of the chief and financial directors. Sun (2015) examines the relationship between accounting expert financial finance (CFO's financial expertise) and concerns about corporate governance. Darmadi (2013) examines the effect of board member education on corporate performance in developing countries such as Indonesia.

This research is an extension of Loyeung's previous research (2014) which examines the financial director's accounting talents, compensation of finance director, and director's turnover. This study differs from previous research in several respects. First, this research is conducted in Indonesia which is one of the developing Asian countries. Second, this study uses financial expertise as an independent variable. Third, previous research focused on financial director (CFO) while in this study focused on the board of directors.

Our study is important in the following ways. First, this research is interesting because there is still little literature and discussion that discuss about financial expertise especially in Indonesia. Secondly, this topic becomes very interesting because of the growing issue of Sarbanes Oxley Act or commonly known by the acronym SOX / SOA and the change of accounting standards in Indonesia. This study entitled the influence of financial accounting of directors to compensation and directors turnover in non-financial companies in Indonesia.

\subsection{Formulation of the problem}

This study aims to examine the effect of financial expertise of directors on compensation and directors turnover in Indonesia. This study provides the literary benefit for the development theory because of the lack of literature on financial expertise, directors compensation and change of directors in Indonesia. In addition, for the research company it can be useful for practitioners in applying compensation and change of directors by considering financial expertise of directors.

\subsection{Research purposes}

This study aims to develop Loyeung's previous research (2014). This study aims to examine the effect of fianancial expertise of directors on compensation and director's turnover in Indonesia. This research is expected to give a new evidance for the financial expertise literature and give different results because it's done in developing countries.

\subsection{Benefits of research}

This research provides the literary benefit for the development of theory because of the lack of literature on financial expertise, directors compensation and directors turnover in Indonesia. In addition to this research company can be useful for practitioners in 
applying compensation and change of directors by considering fianancial expertise of directors.

\section{Theoretical Review}

\subsection{Theoritical review} Agency Theory

When owner hires another party to perform a service in his compeny, there is an interest conflict with the related party. The owner of the entity is the principal and the other party employed is referred to as the agent. In performing its duties the principal delegates the authorization of decision-making in the hands of the agent. In a company, the shareholder as the principal and the chief executive as the agent. At the lower level the chief executive becomes principal and the manager of the business unit becomes his agent (Anthony, 2005).

The agency theory assumes that all individuals act for their own interests. Agents are assumed to receive job satisfaction not only from financial compensation but also from additional directly involved in agency relations (Anthony, 2005). In this theory is known as agency problems. An agent is more likely to prioritize its interests compared with the interests of business or shareholders (Muharam, 2004). Therefore principal will provide compensation as a form of positive motivation to the agent.

\subsection{Research Accomplished}

The discussion of the relationship between principal and agents has become a very interesting and contentious topic. Beginning with the Enron, WorldCom, and other multinational case scandals, has sparked regulatory reforms related to agency responsibilities in reporting their corporate finances. Following the emergence of related scandals The responsibility of the agent in reporting the company's finances comes the Sarbanes-Oxley Act or SOX / SOA regulation. This regulation contains provisions that one of them is the agents, especially the chief executive (CEO) and the financial director (CFO), must have accountable accounting principles. This sparked a lot of debate that assume that in carrying out its duties, a director must have talent or mastery in accounting. Burks

(2007) investigated the impact of SOX and

re-reporting on compensation and replacement of CEOs and CFOs. Berks (2007) found no significant association between CEO turnover to re-reporting after SOX, but there was a significant relationship between CEO turnover to SOX re-reporting. This supports that SOX rules that require the $\mathrm{CEO}$ and $\mathrm{CFO}$ to have accounting qualifications in financial reporting.

Loyeung (2014) examined the relationship between $\mathrm{CFO}$ accounting talents on compensation and CFO turnover. In his research, Loyeung (2014) took accounting reporting error levels at the turn of US GAAP to IFRS as a measure of accounting talent variables. Loyeung (2014) found that there was a positive relationship Between $\mathrm{CFO}$ accounting talents on CFO compensation during IFRS transition period and during IFRS full adoption period. In addition Loyeung (2014) finds there is an inverse relationship between $\mathrm{CFO}$ accounting talents on CFO turnover in the transition year and full adoption years.

Colli et.al (2016) examines the Earning Restatement, the Sarbanes Oxley Act, and the Disciplining of Chief Financial Officers. Colli et.al (2016) examines the relation of earnings reporting and the impact of the Sarbanes Oxley Act on the disciplinary director of finance.Colli et . (2016) used a change of financial director as a result of the disciplinary action of the finance director.Colli et.al (2016) found that after the issuance of SOX regulations the finance director was more severe in making earnings reports than in the preSOX period. .al (2016) is the financial director asked to have more financial expertise to account for the report.

Sun et.al (2014) examines CFO financial expertise and corporate governance concerns Evidence from S\&P SmallCap 600 Index. Sun (2014) investigates the relationship between financial director's financial expertise on good corporate governance.In Sun's study (2014) CPA (Certificate Public Accountant), MBA (Master of Business Administration), tenure and age of finance director as a measurement tool to measure financial expertise. Sun (2014) found that negatively accounting skills of 
finance director related to Concerns good governance.That is, in his research accounting skills of finance director can reduce the concerns of good corporate governance principles. This led investors to become confident with the company and lack of supervision from investors.

Woning (2014) examines the effect of job complexity and performance of financial director on compensation of finance director. Woning research (2014) conducted in Indonesia. Woning (2014) uses company size, business segment, free cash flow, and long-term debt as a proxy to measure the complexity of work.And using the positive accrual discretionary, growth opportunities and age of the finance director to measure the performance of finance director.From the results of his research, woning 2014) found that the compensation of the finance director only had an effect on one of the measurement of the complexity of the work ie firm size, as well as the effect on one of the performance measures ie growth opportunities. CFO compensation has no effect on business segments, free cash flow, long-term debt, positive accrual discretionary, and CFO age.

Darmadi (2013) examines the effect of board of director's education on company performance in Indonesia. Darmadi (2013) uses the proportion of CPA and postgraduate degrees that the board has as a proxy to measure the education of directors. In addition Darmadi (2013) separates the education of directors by dividing it into overseas graduates and graduates in the country. Darmadi (2013) found that directors with educational qualifications showed better performance than those without qualifications.

\section{Hypotheses Development}

IFRS is the biggest innovation in world of accounting. IFRS is considered able to add more comprehensive information quality than GAAP in accounting reporting (Krismiaji, 2016). Indonesia as a developing country started gradually in adopting IFRS. Started in 2008 and full adoption in 2012. The process of changing from GAAP to IFRS is increase demands for board of directors to learn new standards and take responsible in staff training, users, analysts, creditors, and investors. The impact of a error in adapting GAAP to IFRS is considered be an indicator of accounting talent (Loyeung, 2014).

The accuracy of accounting reporting becomes the standard of information quality conveyed. Supriharin (2013) proves that IFRS adoption can improve the relevance of equity and profit values against stock prices. In process of adopting IFRS, the increase value in the financial statements is considered as a key to success level in implementing the new standards. This success level is can be evidence of the existence of financial expertise. Board directors with financial expertise are expected to be better implement new financial standards than directors who do not have financial expertise. In accordance with the idea that directors who have successfully implemented IFRS in the transitional year will receive greater compensation compared to the less successful directors of IFRS, the first hypothesis will show as follows:

H1. There is positive association between the director's financial expertise and director's compensation level in transistion years.

Board of directors usually hired between 3 to 5 years. One component in compensation usually consists of base pay and bonuses. Annual increases in basic salaries are usually determined on the basis of employment contracts. Therefore, in his research Loyeung (2014) did not expect a significant increase in total compensation from the transition year to the full adoption year. However, board of directors who has better peformance will get a higher bonus (Loyeung, 2014). Bonus is a component that exists in total compensation. This will build the second hypothesis that the company will provide bonuses and raise greater compensation to board of directors with financial expertise than less financial expertise. Therefore, board of directors with financial expertise will receive a greater compensation increase from the company compared to the less financial expertise.

$\mathrm{H} 2$. There is positive association between the director's 
financial expertise and increase of director's

compensation level in adoption years.

The lack of financial expertise can cause weak internal control of the company. Companies with weak internal controls which get lower compensation and experience will more frequent in board turnover (Wang, 2010). This is similar with Loyeung's (2014), time of IFRS adoption is considered as momentum of a change in accounting standards. During the adoption period the directors are considered be in the same situation and are expected to implement the new standards better. Directors who have no expertise in applying new standards are likely to be replaced (Colli, 2016). This builds a third hypothesis, the board of directors with financial expertise will be able to implement the new standards and will be maintained by the company compared to the board of directors without the financial expertise.

H3. There is negative association between the director's financial expertise and director's turnover in transistion years.

\section{Research Methods}

\subsection{Population and Sample}

This research is a quantitative research whose data obtained through financial statements and annual reports of non-financial companies listed on the Indonesian stock exchanges. Samples will select on purposive sampling as follows:

Table 1 Sample Characteristics

Non-financial companies listed on IDX 2011 and 2012

Less :

Do not have complete annual report

Not explaining the profile of the board of directors

Does not contain directors' compensation

The population that includes non-financial companies in Indonesia Stock Exchange in 2011 and 2012 are 253 companies. After selecting samples, there are 51 companies that meet the characteristics of sample. This research was conducted in Indonesia and used a sample of non-financial companies listed on the Indonesian stock exchange. Previous research was conducted in Europe, America and Australia. This research was conducted in Indonesia which is a developing country. Indonesiais different from previous research, it is hoped this research can add to the evidence of the influence of financial expertise on compensation and change of directors in developing countries.

\subsection{Types and Sources of Data}

The types and sources of data used in this study is secondary and historical data, so in the data collection techniques using data base collection techniques. Database retrieval technique is done to obtain secondary archive data. In this research, data archive technique obtained from the official website of Indonesia stock exchange. We collect data through historical data by accessing the official site of the Indonesian stock exchange.

\subsection{Data Collection Technique}

Sampling technique using non-random sampling method is purposive judgment sampling or sampling using special criteria. The purpose of this method is to take samples based on specific criteria based on certain considerations. purposive judgment sampling to avoid the imbalance of data between years to be studied.

Samples taken must meet certain criteria.First sample must be non-financial companies because for financial companies there are different composition in financial reporting. Secondly, the sample must have complete financial information in its financial statements. Third, the sample must have data on the members of the board of directors ranging from name, title, term of office, and total amount of compensation to the board of directors. Fourth, the sample must be listed on the Indonesian stock exchanges in the two years studied ie the transition year 2011 and the year of full adoption 2012. 


\subsection{Research Model and Variables Measurment}

This study will use multiple regression model.

Here is a multiple regression model that will be used to test the first and second hypothesis.

\section{Model Hipotesis 1:}

$$
\begin{aligned}
& \mathrm{COMP}_{\mathrm{t}}=\beta 0+\beta 1 \mathrm{CPA}+\beta 2 \mathrm{MBA}+\beta 3 \mathrm{TENURE}+ \\
& \beta 4 \mathrm{AGE}+\beta 5 \mathrm{SIZE} . \ldots \ldots . .(1)
\end{aligned}
$$

\section{Model Hipotesis 2:}

$$
\begin{aligned}
& \Delta \mathrm{COMP}_{\mathrm{t}+1}=\beta 0+\beta 1 \mathrm{CPA}+\beta 2 \mathrm{MBA}+\beta 3 \\
& \mathrm{TENURE}+\beta 4 \mathrm{AGE}+\beta 5 \mathrm{SIZE} \ldots \ldots \ldots .(2)
\end{aligned}
$$

$\mathrm{COMP}_{\mathrm{t}}$ :Total of board direstors compensation in transition year (2011)

$\triangle \mathrm{COMP}_{\mathrm{t}+1}$ : Boards directors compensation increase In adoption year (2012)

CPA :Proportion of Board directors Certified professional accountant.

MBA :Proportion of magister Bussiness administration.

TENURE :Proportion of year service of directors

AGE :Proportion of directors age

SIZE :Size of company

To test hypothesis 3, this study will use logistic regression model. Here is a logistic regression model that will be used to test the third hypothesis.

\section{Model Hipotesis 3:}

$$
\begin{aligned}
& \text { TURNOVER }= \beta 0+\beta 1 \mathrm{CPA}+\beta 2 \mathrm{MBA}+\beta 3 \\
& \text { TENURE }+\beta 4 \mathrm{AGE}+\beta 5 \mathrm{SIZE}+\varepsilon
\end{aligned}
$$

TURNOVER $_{\mathrm{t}+1}$ : Directors turnover in adoption year.

CPA :Proportion of Board directors Certified professional accountant.

MBA :Proportion of magister Bussiness administration.

TENURE :Proportion of year service of directors

AGE :Proportion of directors age

SIZE :Size of company

\section{Operational Variables \\ Dependent Variables \\ Directors' Compensation}

Compensation is all income in the form of money, goods directly or indirectly received by employees in return for services. Woning (2014) uses $\log$ of total compensatin as a proxy for compensation. Ulupui (2015) examines the effect of family ownership, directors \& commissioners' closeness to the controlling owners of the compensation of directors and company commissioners in the Indonesian capital market also using log of total compensation as a proxy of compensation. In accordance with the previous research, this study will also use the natural log of the total compensation of the directors as the proxy of the directors compensation variable.

\section{Compensation Increase.}

Loyeung (2014) finds that the company will provide bonuses for and greater compensation increases to directors who successfully implement new financial standards in the company. Bonus is one of the components in compensation. A bonus increase will result in an increase in total compensation received by the board of directors. The increase in compensation will be measured using the difference in total compensation in 2012 and 2011.

\section{Directors' Turnover}

The board of directors is the person responsible for company. Board of commissioners entrust decision-making to the board of directors. The board of commissioners prefer board of directors who understand in accounting because in preparing and analyzing financial statements requires financial expertise (Zhao, 2016). Previous studies have argued that directors with poor accounting skills and error in reporting earnings are more often superseded by skilled directors. Substitution of the board of directors can be seen the company's annual report.

The proxy for directors' turnover shall be measured by directors' turnover. Directors's turnover is measured by matching the names of the board of directors in 2011 and 2012. If there is a change it will be given a value of one and if there is no change it will be given a value of zero.

\section{Independent Variaebel}

\section{Financial expertise}

The independent variable of this research is financial expertise (financial expertise) were measured using the proportion of professional certification (CPA) board of directors, the proportion of post-graduate degree (MBA) board of directors, the directors working period (tenure) and ages of directors. If directors have accounting professional qualification (CPA) and postgraduate degree (MBA) then rated one and if not then given a zero value for each variable. Then the value of the accounting professional qualification (CPA) will be totaled and divided by the number of existing board members. The same thing applies to the variable glasses graduate (MBA). The tenure of the directors (tenure) will be measured by using a long-serving company and the age of the directors will be measured using the proportion of the age of the board of directors. 


\section{Variable Control \\ Company size}

To support the research, this study used a control variable. The control variables used are the size of the company that will be measured using a natural log total assets (TA). Company size measured by total fixed assets and current assets acquired from the company's financial statements. Total assets have been frequently used as a measure of the size of the company in several studies. Companies that have a large size is more interested in hiring the director mememiliki keahlian.Selain large-sized enterprise is deemed better able to provide a great compensation to the board of directors (Loyeung, 2014).

\section{Results And Discussion}

\section{Descriptive statistics}

Based on the second table of descriptive statistics can know the number of samples to be tested as many as 51 companies. From the table of descriptive statistics can be seen in total compensation in 2011 have an average value of $22.242,18.5$ maximum value, minimum value of 25.9 and a standard deviation of 1.4803. Total compensation in 2012 have an average value of 22.534, 26.3 maximum value and minimum value of 19.7, and a standard deviation of 1.4447 .

The increase in the compensation of directors has an average value of 20.524 , the maximum value of 25 , the minimum value of 16.6 , and a standard deviation of 1.9655. Substitution of directors has an average value of 0.451 , the maximum value of 1 , the minimum value of 0 and a standard deviation of
0.5025. Age of directors in 2011 have an average value of 47.778 years, the maximum of 61.3 years, the minimum value of 30 and a standard deviation of 5.5558. Age of directors in 2012 have an average value of 48.098 years, the maximum of 62.3 years, 35.5 years minimum value, and a standard deviation of 5.5426 .

Period servant of directors in 2011 have an average value of 5,218 years, the maximum value of 25.7 years, the minimum value 0 years, and the standard deviation of 5.4008. Period servant of directors in 2012 have an average value of 5.147 years, 26.7 years maximum value, minimum value 0 years, and the standard deviation of 4.9897 . Accounting certification in 2011 have an average value of 0,020 , the maximum 4 , the minimum value of 0 and a standard deviation of 0.745 . Accounting certification in 2012 have an average value of 0.019 , the maximum value of 3 , the minimum value of 0 and a standard deviation of 0.709 . Post-graduate degree in 2011 have an average value of 0,302 , the maximum value of 1 , the minimum value of 0 and a standard deviation of 0,2590 . Gelar graduate in 2012 have an average value of 0.331 , the maximum value of 1 , the minimum value 0 , and standard deviation of 0.2301 .

Total compensation of directors and directors using the nominal rupiah rise in full so as to simplify the data so that the data to be normal by using the natural logarithm. For ages directors and a man of directors using the unit of money later in proporsikan with the number of board members. accounting certification and post-graduate degree using a proportion of the number of members who have accounting certification and post-graduate degree.

Table 2. Descriptive Statistics Research Model

\begin{tabular}{|c|c|c|c|c|c|}
\hline & $\mathrm{N}$ & Min & $\operatorname{Max}$ & mean & Std. deviation \\
\hline COMP_t & 51 & 18.5 & 25.9 & 22.242 & 1.4803 \\
\hline COMP_ti & 51 & 19.7 & 26.3 & 22.534 & 1.4447 \\
\hline Ln_ $\triangle \mathrm{COMP}$ & 51 & 16.6 & 25.0 & 20.524 & 1.9655 \\
\hline Turnover & 51 & 0,00 & 1.0 & .451 & .5025 \\
\hline AGE_t & 51 & 30.0 & 61.3 & 47.778 & 5.5558 \\
\hline AGE_ti & 51 & 35.5 & 62.3 & 48.098 & 5.5426 \\
\hline TENURE_t & 51 & 0,00 & 25.7 & 5,218 & 5.4008 \\
\hline TENURE_ti & 51 & 0,00 & 26.7 & 5.147 & 4.9897 \\
\hline CPA_t & 51 & 0,00 & 0.4 & 0,020 & .0745 \\
\hline CPA_ti & 51 & 0,00 & 0.3 & 0,019 & .0709 \\
\hline MBA_t & 51 & 0,00 & 1.0 & 0,302 & .2590 \\
\hline MBA_ti & 51 & 0,00 & 1.0 & 0.331 & .2301 \\
\hline Size_t & 51 & 23.7 & 32.3 & 28.266 & 1.7093 \\
\hline
\end{tabular}


Source: SPSS 17.0

First Hypothesis Testing Results (H1)

The first hypothesis in this study is the financial expertise of directors having an effect positively to the compensation of directors in transition (2011).

Table 3 Results of regression test the first hypothesis

\begin{tabular}{lccc}
\hline \multicolumn{1}{c}{ variables } & \multicolumn{1}{c}{ Dependent Variable = Compensation of Directors in 2011 } & \\
\hline constants & Regression coefficient & t Count & Sig \\
AGE_t & 6.825 & 2.218 & 0,032 \\
TENURE_t & -0.011 & -0.327 & 0,745 \\
CPA_t & 0,008 & .227 & 0.821 \\
MBA_t & -1.926 & -0.824 & 0,414 \\
size_t & 0,848 & 1,249 & 0.218 \\
adjusted R2 & 0.555 & 5.227 & 0,000 \\
Regression & & & 0.352 \\
\hline Observation & & & 0,000 \\
\hline
\end{tabular}

Source: SPSS 17.0

Based on Table 3 the results of multiple regression test the first hypothesis, the value of the adjusted R2 of 0.352 which means that the variability of the compensation of directors in 2011 can be explained by $35.2 \%$ by the age variable directors, past the man of directors, the accounting profession degree (CPA), and the title of the post bachelor (MBA) directors in 2011. the remaining $64.8 \%$ is explained by other variables not included in the regression model.

Under the influence of the simultaneous test $(\mathrm{F}$ test) was obtained calculated $F$ value of 6,428 and 0,000 levels in the regression sinifikansi smaller than 0.05, which means that the independent variable financial expertise simultaneously affect variable compensation. However, financial expertise can simultaneously affect the variable compensation due to the directors of the significance of the size of the company tingtat 0,000 less than 0,005 . If the record per variable, the variable age of directors (Age) significant at 0.745 , Variable time servant of directors (Tenure) is significant at 0.821, CPA variables significant at 0,414 , and an MBA variables significant at 0.218 . The fourth significant value financial expertise variable value is greater than 0.05 , so there is no variable financial expertise that can simultaneously affect the variable compensation of directors. The first hypothesis is not supported.

Based on the partial test ( $t$ test) output results of the regression test first hypothesis can be inferred by the regression equation as follows:

$$
\begin{aligned}
\text { KOMP }_{\mathrm{t}}= & 6.825 \text { to } 1.926 \mathrm{CPA}+0,848 \mathrm{MBA}+0,008 \\
& \text { TENURE }-0,011 \mathrm{AGE}+0.555 \mathrm{SIZE}
\end{aligned}
$$

The constant of 6.825 states that if the independent variables held constant, the total compensation of directors at 6.825. CPA negative regression coefficient 1.296 , which means every variable CPA up one unit will reduce the compensation of directors amounted to 1,926 with the assumption that the other independent variables are fixed. MBA worth positive regression coefficient 0.848 , which means every variable MBA rose one unit will increase the compensation of directors amounted to 0,848 with the assumption that the other independent variables are fixed.

Servants period is positive coefficient of 0.008 , which means every time variable servant (Tenure) moved up one unit will increase the variable compensation of directors amounted to 0,008 with the assumption that the other independent variables are fixed. AGE negative regression coefficient of 0.011 , which means every variable AGE up one unit will reduce the compensation of directors amounted to 0,011 with the assumption that the other independent variables are fixed. Regression coefficient of firm size (Size) is positive 0.555 means that every variable firm size (Size) moved up one unit will increase the variable compensation of directors amounted to 0.555 assuming other independent variables are fixed.

Of the four variables that define financial expertise no positive effect on the variable compensation of directors. However, the control variables firm size have a significant effect in predicting the compensation of directors. This is in contrast with previous studies that examined the 
financial director of financial expertise to the compensation of financial directors in the turn of the IFRS transition.

Loyeung (2014) argues the greater the directors serving in his position, the better the decisions related to their responsibilities. Nourayi (2008) also reported the same thing associated time servant (Tenure) and ages of directors (Age) against compensation. Post-graduate degree (MBA) became one of the accounting variables that have a positive influence on the compensation of directors, MBA and CPA is used as a measurement of financial expertise based on the assumption that graduates master the business can provide knowledge about the business and also a better understanding of the accounting (Sun, 2013).

However, there are some studies that show similar results to the study. Variable age of directors (AGE), accounting certification (CPA), the directors post-graduate degree (MBA), and a man of directors (Tenure) did not show the same results in previous studies. Nourayi (2008) found the compensation of directors is influenced significantly by the performance of directors but is not influenced by the length of time the man of the board of directors and ages of directors. Guner (2008) also found that the compensation of directors is not a significant increase to the directors who have financial expertise.

This is because few samples of directors members holding accounting certification that the sample less representative of the population accounting for the certification test in this study. The same thing happened in post-graduate degree (MBA) in which not all members of the board of directors holds a post-graduate degree. In addition, only $35.2 \%$ variable financial expertise can explain compensation while the remaining $64.8 \%$ is explained by other variables not included in the financial expertise. From these results, the researchers concluded less capacity so that the sample variable financial expertise financial expertise in Indonesia are less able to explain the compensation of directors.

Principal delegate authority to the directors in making decisions. In selecting directors, principals would prefer directors who have financial expertise and provide compensation as a form of motivation to increase profits. However, in this study did not show a positive effect of the financial expertise of directors of the compensation of directors. This study proves that the agency theory only a theory and have no effect on the control of management practitioners. This proves that the owner of the company did not apply the principle of agency in determining compensation.

\section{Second Hypothesis Testing Results (H2)}

The second hypothesis in this study is the financial expertise of directors (financial expertise) positive effect on the increase in the compensation of directors in full adoption.

Table 4 Results of the second hypothesis regression test

\begin{tabular}{lcc}
\hline & \multicolumn{2}{c}{ Dependent Variable $=$ Increase in Compensation of Directors In the Year 2012} \\
\cline { 2 - 3 } \multicolumn{1}{c}{ variables } & Regression coefficient & Sig \\
\hline constants & 1,273 & 0.754 \\
AGE_t & -0.024 & 0.615 \\
TENURE_t & -0.022 & 0.676 \\
CPA_t & 3,853 & .227 \\
MBA_t & -0.780 & .435 \\
size_t & 0.731 & 0,000 \\
adjusted R2 & & 0,365 \\
Regression & & 0,000 \\
\hline Observation & & 51 \\
\hline
\end{tabular}

Source:SPSS 17.0

Based on Table 4 the results of multiple regression test hypotheses Second, the value of the adjusted R2 of 0.365 which means that the variability of increase in compensation of directors in 2012 can be explained by $36.5 \%$ by the age variable directors, past the man of directors, the accounting profession degree (CPA), and the title graduate (MBA) directors in 2012. the remaining
$63.5 \%$ is explained by other variables not included in the regression model.

Under the influence of the simultaneous test ( $F$ test) was obtained regression significance value of 0.000 is smaller than 0.05 , which means that the independent variable financial expertise of directors simultaneously together influencing variable compensation increases directors (LN $\triangle \mathrm{COMP}$ ). 
However, when seen from the significant value of each variable financial expertise of directors obtained a value as follows. Age of directors (Age) has a significant value of 0.615 . Period servant of directors (Tenure) has a significant value of 0.676 . Directors accounting certification (CPA) has a significant value of 0.227 . Directors post-graduate degree (MBA) has a significance value of 0.435 . As for the control variables firm size is 0,000 .

Although the simultaneous test (F test) showed the second hypothesis is supported not least due to the significance level of firm size (Size) 0,000 less than 0.05 . If the terms of the significance value per independent variable age of directors, servants past directors, directors accounting certification, and post-graduate degree directors have a significance value greater than 0.05 . Thus, we can conclude the second hypothesis is not supported. That is, the financial expertise of directors positive effect on the increase in the compensation of directors in full adoption.

Based on the partial test ( $t$ test) results of the second hypothesis regression test output can be concluded with a regression equation as follows:

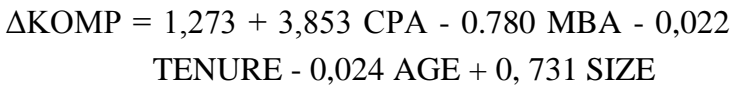

The constant of 1.273 states that if the independent variables held constant, the increase in the compensation of directors amounted to 1,273. CPA regression coefficient is worth 3,853 , which means every variable CPA up one unit will increase the directors compensation increase of 3.835 with the assumption that the other independent variables are fixed. MBA worth the regression coefficient 0.780 , which means every variable MBA rose one unit will reduce the increase in the compensation of directors amounted to 0.780 with the assumption that the other independent variables are fixed.

Time servant negative coefficient 0.022 , which means every time variable servant (Tenure) moved up one unit will lower variable compensation increases of directors of 0.022 assuming that the other independent variables are fixed. AGE negative regression coefficient of 0.024 , which means every variable AGE up one unit will reduce the increase in compensation of directors amounted to 0,024 with the assumption that the other independent variables are tetap.Koefesien regression firm size (Size) is positive 0.731 means that every variable firm size (Size) ride one unit will increase the variable compensation increases with the assumption of directors amounted to 0.731 other independent variables are fixed.

Control variables significant effect of firm size in predicting the increase in variable compensation of directors but not financial expertise of directors.
This is not in line with previous studies that examined the financial expertise to the financial director compensation increases or bonuses finance director in pergatian adoption of IFRS (Loyeung, 2014).

Of the four variables that define financial expertise accounting certification (CPA), a postgraduate degree (MBA), the age of the directors (Age), and a man of directors (Tenure) no positive effect on the variable compensation increases directors. Variable age of directors (AGE), a postgraduate degree (MBA), and a man of directors (Tenure) did not show the same results in previous studies loyeung (2014). This does not indicate that employers give more compensation increases based on the qualifications of directors accounting (CPA), a postgraduate degree (MBA), the age of the directors (Age), and a man of directors (Tenure). It does not agree with the previous literature that says that their accounting qualification (CPA) can reduce the concerns of shareholders in managing companies (Sun, 2015).

Moreover, it proves that in Indonesia the change does not affect the company's financial standards in selecting directors with financial expertise better. This is in line with research Guner (2008) who found that the compensation of directors is not a significant increase to the directors who have financial expertise. With the change of financial standards will put new pressure on the directors in the financial report and implement internal control. However, it is not proven in this study.

Agency theory explains that the principal and agent have different interests in menjelankan company. With the contract is expected to memotivator agent intensive work harder and reduce the interest difference. However, in this study it is not proven by the practitioner. Principals do not provide a boost in the form of increase in compensation to his agent at the time of the change of the financial standards that require understanding and relearning by the agency in preparing the financial statements and internal control.

Lack of encouragement in the form of increase in compensation from the principal to the agent can be caused by several things. First thing, this could be due to the turn-based financial standards of SFAS SFAS GAAP into IFRS based pelapran less an impact on the company's financial and management control of the company. Second, in the absence of intensive labor contracts that provide bonuses such as cash or stock. This will cause a misalignment of interest between the agency with the interests of the company.

\section{Third Hypothesis Testing Results (H3)}

The third hypothesis in this study is the financial expertise of directors negatively affect the change of directors during the year of IFRS adoption. 
Table 5 Results of regression test a third hypothesis

\begin{tabular}{lcc}
\hline & Dependent Variable = Change of Directors of the Year 2012 \\
\cline { 2 - 3 } \multicolumn{1}{c}{ variables } & Regression coefficient & Sig \\
\hline constants & -3234 & 0552 \\
AGE_t & -0012 & 0841 \\
TENURE_t & -0046 & 0482 \\
CPA_t & 2,487 & 0539 \\
MBA_t & -2499 & 0068 \\
size_t & 0160 & 0400 \\
pseudo R2 & & 0128 \\
Onimbus Test & & 0402 \\
\hline Observation & & 51 \\
\hline
\end{tabular}

Source: Data Olah SPSS 17.0

Based on Table 5 the results of multiple regression test hypotheses Third, the magnitude of Pseudo R2 value of 0.128 which means that the variability of the variable change of directors in 2012 can be explained by $12.8 \%$ by the age variable directors, past the man of directors, the accounting profession degree (CPA), and the title graduate (MBA) directors in 2012. the remaining $87.2 \%$ is explained by other variables not included in the regression model.

Under the influence of the test simultaneously (Onimbus test) was obtained at 0.402 regression sinifikansi value greater than 0.05 , which means that the independent variable age of directors (AGE_ti), past the man of directors (TENURE_ti), the title of the accounting profession (CPA_ti), and a postgraduate degree (MBA_ti) simultaneously together does not affect the turnover variable directors ( $\triangle$ TURNOVER). The third hypothesis is not supported, which means financial expertise of directors (financial expertise) should not adversely affect the turn of the directors during the year of IFRS adoption.

Moreover, the significance of each independent variable age of directors amounted to 0.841 , a period of directors servant $0.482,0.539$ accountants professional degree and post-graduate degree 0.068 showed significantly greater value than the value of $0.05 \%$ significance test. So that the results showed no significant effect of variable financial expertise of directors to replace any directors at year's adoption of IFRS.

Based on the results of logit regression test output can be concluded with a third hypothesis regression equation as follows:

$$
\begin{aligned}
& \text { ATURNOVER }=-3.234+2.487 \mathrm{CPA}-2,499 \mathrm{MBA} \\
& -0,046 \text { TENURE }-0.012 \mathrm{AGE}+
\end{aligned}
$$

\section{$0.160 \mathrm{SIZE}+\varepsilon$}

constants for -3.234 stated that if the independent variables held constant, the change of directors has a value of -3.234 one unit. CPA regression coefficient 2.487 , which means turnover worth directors will be increased by $12.025(\mathrm{e} 2,487)$ times for each unit increase in directors accounting certification (CPA) than companies that did not experience the change of directors if other variables held constant. MBA worth the regression coefficient -2.499 , which means the change of directors will increase by 0.082 (e-2.499) times for each unit reduction directors post-graduate degree (MBA) than companies that did not experience the change

of directors if other variables held constant. Regression coefficient tenure worth -0.046, which means the change of directors will increase by 0.955 (e-0.046) times for each unit decrease in time servant of directors (Tenure) than companies that did not experience the change of directors if other variables held constant. Age regression coefficient of directors (Age) worth -0.012 , which means the change of directors will increase by 0.988 (e-0.012) times for each unit decrease in the age of the directors (Age) than companies that did not experience the change of directors if other variables held constant. Regression coefficient of firm size (Size) worth 0.160 which means the change of directors will be increased by $1,173(\mathrm{e} 0,160)$ times for each unit increase in firm size (Size) than companies that did not experience the change of directors if other variables held constant. Control variables company size also showed no significant effect in predicting the turnover variable directors. This is in contrast from previous studies (Loyeung, 2014). Zhao (2016) find a company that does the reporting back to prefer hiring directors 
who have accounting qualifications both in terms of experience and knowledge of accounting. The results of this study do not prove it.

Bhagat (2010) found that the financial expertise berepengaruh no significant play an important role in the decision to replace the company's directors. This study also found no significant effect of financial expertise of directors to replace any directors at the time of the adoption of IFRS penih. In the implementation, the company would seek to memepekerjaan director with accounting experience and qualifications better than the previous one. However, the results of this study contrasts with that. This may be caused by at least a sample of firms in this study as well as research time using only two years of research. Moreover, it proves that in Indonesia the change does not affect the company's financial standards in selecting directors with financial expertise better.

\section{CONCLUSIONS AND SUGGESTIONS}

This study provides evidence of the effect of financial expertise of directors related to the compensation of directors and change of directors in non-financial companies in Indonesia in 2011 through 2012. This study used four variables to define financial expertise is accounting certification (CPA), a postgraduate degree (MBA), age directors (aGE), past the man of directors (TENURE). There are several conclusions that can be drawn from this study. First, there are no positive effect of financial expertise of directors in Indonesia. Second, there is a positive effect of financial expertise of directors to the increase in the compensation of directors. Third, there are no negative influence between financial expertise of directors to replace any directors in Indonesia.

Control variables associated company size significantly to the compensation of directors and compensation increases. This explains the larger the company the greater the rise in compensation and compensation can be awarded. However, the age variable directors, servants past directors, directors of certification and post-graduate degree directors failed to define the effect of financial expertise to compensation and replacement of directors. This may be caused because the low variability of the four variables financial expertise in explaining the dependent variable. This proves the change does not affect the standard of financial reporting and management control in non-financial companies in Indonesia.

Moreover in practice the company would choose directors who have expertise and understanding of accounting, so the owner of the company can be more confident in delegating authority to the directors. And the company will provide compensation and bonuses in intensive employment contract as a form of dorangan for an agent to work harder. However, in practice the lack of educational background of directors holds a CPA and MBA, as well as the limitations of working life and also the life of the directors in the employment contract to make variable the CPA, MBA, age directors and a man of directors less into the right variables in measuring financial expertise of directors in Indonesia.

This study has several different limitations. First, this study uses only two years of research, namely 2011 and 2012. As well as limited the sample to nonfinancial companies in Indonesia. Researchers speculate that the small study led to a lack of representativeness of the sample to test the hypothesis. Second, the study only used as a control variable sized companies while there are many other variables such as the complexity of the work, the size of the board of directors, the value of stock returns, and others that can be a supporter of research related to the compensation of directors. The study only examined the overall board of directors related to the variables measured using proportions.

Based on research that has been done on these results suggest for the company to hire directors who have belekang educational background in business and have accounting certification (CPA). In addition, the company may consider the compensation and compensation increase through time servant of directors, directors age, and educational background as an MBA and CPA directors owned by members of the board of directors. For education, this research may be relevant literature and adds to evidence of financial expertise, compensation, and a change of directors in Indonesia.

Suggestions for further research are expected to increase the scope of the sample in terms of years and also studied industrial sector. Further research is also expected to add variables related to financial expertise for R-square test is obtained by a fairly small variability in explaining financial expertise to compensation and replacement of directors. In addition, further research can also be specifying the object of study of the board of directors became managing director or finance director. 


\section{References}

Adhiyatma, C. (2014). The occurrence indication Earnings Management Practices Around Substitution Chief Executive Officer (CEO) On the Public Company in Indonesia.

Angela K. Goree, SM (2011). The Role Of Technical Expertise In Firm Governance Structure: Evidence From Contractual Incentives Chief Financial Officer. Strategic Management Journal, 771-786.

Anthony, RN (2005). Management Control System.

Jakarta: Four Salemba.

Armstrong, CS (2010). Chief Executive Officer of Equity Incentive And Accounting irregularities. Journal of Accounting Research.

Burks, JJ (2007). Sarbanes-Oxley And The Effect Of

Restatements On Compensation And Ceo And CFO Turnover.

Bhagat, S. (2010). CEO Educational, CEO Turnover, and Firm Peformance. American Journal Of Business.

Committee, BR (1999). Report And recomendations

Of The Blue Ribbon Committee On Teh Improving Effectiveness Of Corporate Audit Committees ,. New York: The NYSE And The NASD.

Darmadi, S. (2013). Board Members' Education And

Firm Performance: Evidence From A Developing

Economy. International Journal Of Commerce

And Management.

Denton Colli, AM (2016). Earnings Restatements, The Sarbanes-Oxley Act, And The Disciplining Of Chief Financial Officers. Journal of Accounting, Auditing and Finance.

Gore, AK, Matsunaga, S., \& Young, E. (2011). The Role Of Technical Expertise In Firm Governance Structure: Evidence From Contractual Incentives Chief Financial Officer. Strategic Management Journal.

Guner, A., Malmandier, U., \& Tate, G. (2008). Finance

Expertise of Directors. Journal of Financial

Economics.
Putra Hendra Irawan, AF (2012). Compensation Effect Of Management And Corporate Governance Corporate Tax Management. National Accounting Simposisum Xv.

Loyeung, A. (2014). CFO's Accounting Talent, Compensation, And Turnover. Accounting And Finance.

Muharram, H. (2004). Compensation Chief Executive Officer (CEO) and Performance. Journal of Management \& Organization Studies.

Ross, S. (2013). How Suppress Definitions Of Talent Talent Management. Industrial And Commercial Training.

Sawir, A. (2004). Corporate Policy and Corporate Restructuring. Jakarta: Gramedia Pustaka Utama Pt.

Siti Suprihatin, ET (2013). Impact of Convergence of International Financial Reporting Standards Relevant To The Value of Accounting Information. Journal of Accounting and Finance of Indonesia, 171-183.

Sun, L. (2015). CFO Financial Expertise Corporate Governance Concerns And Evidence From S \& P SmallCap 600 Index. International Journal Of Law And Management.

Suradi. (2012). Know the Sarbanes Oxley Act (Sox / Soa). Retrieved From Board of Education and Training Finance Ministry of Finance: Http://Www.Bppk.Depkeu.Go.Id/Bdk/Palemban g/Attachments/146_Artikel-Soa-Web.Pdf

Tommy Kurniasih, MM (2013). Influence Return On Assets, Leverage, Corporate Governanace, Company Size and Compensation Tax Loss On Tax Avoidance. Bulletin of Economic Studies, Volume 18, No. 1.

Ulupui, IG (2015). The influence of family ownership, Proximity Directors and Commissioners By Owner Control Of Compensation of Directors and Commissioners of the Company In Indonesia Capital Market. Journal of Organization and Management.

Wang, X. (2010). Increased Disclosure Requirements And Corporate Governance Decisions: Evidence From Chief Financial Officers In The Pre- And 
Post-Sarbanes-Oxley Periods. Journal of

Accounting Research.

Woning, RA (2014). Complexity Influence Of Work And Performance Compensation CFO CFO.

Zhao, YX (2016). An Investigate Of Financial Expertise Among the CFO's Hired Improve Following restatement. American Journal Of Business. 